novel point of view. Unfortunately. Drug Discovery does neither. The author's statements are always left open to question because no references are given in the text. so leaving the reader to search the rather poor and imprecise chapter bibliography at the end of the book. Interestingly. this sacrifice was made so that the text, which was written to convey "drama and excitement", should not be disrupted. However without references to contemporary information, the book has lost much scientific credibility.
Perhaps more annoying, there seems to be no benefit of hindsight. The ethical issues that have emerged so forcefully over the past 30 years and now engulf medicine seem to have left no impression. For its easy pace and the stories it relates I would expect the book to have its devotees; but as a serious historical account it falls short of what should be expected. $\square$

Joe Collier is Senior Lecturer and Honorary Consultant in Clinical Pharmacology at St George's Hospiral Medical School. Cranmer Terrace, London SWI7 ORE, UK.

\section{Marking the path}

\section{Peter Laing}

The Biotechnology Business: A Strategic Analysis. By Peter Daly. Frances Pinter, London/Rowman \& Allanheld, Totowa, New Jersey:1985, Pp.155. £16.50, \$25.

THE emergence of an international industry based on molecular biology and immunology is a striking example of the potential economic benefits of government funding of basic research. Equally, however, the commercialization of biotechnology well-illustrates the familiar pattern of technological innovation being avidly and rapidly exploited in the United States and only belatedly in Europe.

In the United States, the availability of venture capital and an entrepreneurial business climate have led to the formation of numerous specialist biotechnology companies. These have been able to attract many of the brightest academic scientists (who would not normally have considered an industrial career) and concentrate upon the problems of developing marketable products. The large, established American companies, aware of the many studies that have shown that technical innovation most often stems from small, flexible and highly-specialized firms, have generally encouraged this process by the provision of research contracts (and even equity finance) for start-up companies, obtaining in exchange the commercial rights to future products.

By contrast, in Europe the start-up company as an engine of technological change has until very recently been a rarity. The brunt of commercialization of new technology has been borne largely by the established industrial companies, in which new ideas have a depressing tendency to be stifled or restrained by corporate inertia and the "Not Invented Here" syndrome. This situation has been compounded by a general lack of contact between industry and academia, particularly in the biological sciences, with the result that the more enterprising scientists have either remained in universities or left for North America.

In Japan, a strong sense of national purpose and a cultural preference for con- sensus solutions have engendered active cooperation between Government, industry and academia with the aim of establishing national priorities for the exploitation of new ideas and identifying the means of bringing them about. Even so. the vehicle for commercialization in Japan has invariably been the established company - indeed, companies in moribund or declining industries have often been selected for revitalization by the injection of funds for biotechnology projects.

The Biotechnology Business is a comprehensive and readable guidebook to the commercial side of the biotechnology industry. As acknowledged by the author, it leans heavily on the excellent Office of Technology Assessment report Commercial Biotechnology, published in 1984, but is less nationalistic in its approach (and also weighs only a quarter of the OTA report's daunting $1.2 \mathrm{~kg}$ ).

Daly's emphasis on strategic analysis, made explicit in his sub-title, has resulted in many interesting case studies. Among them is a timely comment on the American company Genex, warning of the dangers of the company's heavy reliance on a single manufacturing contract for Lphenylalanine with G.D. Searle. This contract was terminated a few weeks after the book was published, plunging Genex into a financial crisis.

The source material for the book appears to have been culled largely from articles in specialist biotechnology magazines. These have tended to concentrate on the newsworthy start-up companies, and there is in consequence an underrepresentation of the strategies which are being adopted by the large chemical and pharmaceutical firms; now that the basic technology is more widely disseminated, such companies are beginning to make real inroads into the market. The likely impact of these moves on the start-up companies suggests not only a volatile employment market for the scientists involved, but, as Peter Daly points out, the development of an even more fruitful area for strategic analysis than the biotechnology industry has provided to date.

Peter Laing is an Assistant Director of N.M. Rothschild Asset Management Lid, New Court, St Swithin's Lane, London EC4P 4DU, UK, which acts as investment adviser to Biotechnology Investments Ltd.

\section{A stir in the primeval soup}

\author{
Jacques Ninio
}

Seven Clues to the Origin of Life: A Scientific Detective Story. By A.G. CairnsSmith. Cambridge University Press: 1985. Pp.123. £9.95. \$17.95.

WE ALL admire the high technology feats that the simplest cells achieve in duplicating chromosomes, translating genes into proteins and adjusting their enzyme activities to their immediate needs. All such pathways are interdependent, each relying on all the others, as in an arch that would collapse if any one of its stones were missing. How did the first cells arise, if life requires, at a minimum, a translation apparatus to make proteins to replicate DNA?

The usual answer is that some $4 \times 10^{y} \mathrm{yr}$ ago the Earth was a gigantic organic reactor producing masses of small molecules, amongst which were amino acids, sugars and nucleotides. Spontaneous polymerizations occurred, leading to nucleic acids that could replicate without the help of enzymes. Some of these "naked genes" acquired control over their environment. The coupling between nucleic acid replication and peptide synthesis became tighter and tighter until it became a strict coding relationship.

Cairns-Smith objects to this view; he believes that primitive organic reactors were more likely to produce tars and sludges than fine biochemical products, and that nucleotides are complex molecules that require sophisticated mechanisms for their production. Also, if a lowtechnology machine is to work, it must avoid the mutual dependency of its parts that is characteristic of more complicated machines. But, he says, the very existence of a primitive life-form made the synthesis of well-defined organic molecules possible. Amongst these, fancy polysaccharides, with no genetic use, might initially have been precursors of DNA or RNA. According to Cairns-Smith, new genes and the machineries they controlled gradually took over from the older forms of life: "None of the fibres in a rope has to stretch from one end to the other ... new 'gene fibres' may be added and others subtracted without breaking the overall continuity".

These ideas are well known among scientists in general but are rarely discussed openly. In the origins-of-life research community, people seek a comfortable corner where they are least likely to interact with competitors. Yet, consider the fundamental issue: is nucleic acid replication conceivable in a prebiotic world? We are flooded with so-called theoretical treatments which generate models of the evolution of prebiotic self-replicating nuc- 